\title{
Study of SNRPN genetic and epigenetic mutations in Prader-Willi and Angelman patients
}

\author{
S. Yu. Chernushyn, N. V. Hryshchenko \\ Institute of Molecular Biology and Genetics, NAS of Ukraine \\ 150, Akademika Zabolotnoho Str., Kyiv, Ukraine, 03143 \\ dnatest@imbg.org.ua
}

\begin{abstract}
Prader-Willi (PWS) and Angelman (AS) syndromes are two clinically distinct genetic diseases associated with multiple physical and cognitive abnormalities. The genetic cause of PWS and AS is the alteration in the 15q11.2-q13 chromosomal region; expression of genes in this region is subject to genome imprinting. Aim. To analyse of the frequency of 15q11.2-q13 rearrangements and epigenetic alterations in the group of Ukrainian patients with PWS and AS. Methods. The methylation status of the $S N R P N$ gene was analyzed by methylation-specific PCR (MSPCR). Results. The absence of unmethylated CpGs in the SNRPN gene promoter was detected in 25 patients (42\%) with the PWS phenotype. In the AS group, the frequency of SNRPN mutations (absence of the hypermethylated CpGs) was observed in $28 \%$ of the cases. In the PWS, group we observed a significant prevalence of males (70\%), but the frequency of the confirmed diagnosis was higher in females ( $56 \%$ vs $36 \%$ ). A lower than expected detection rate in the PWS and AS groups could be due to both clinical and method limitations. Conclusions. Analysis of the SRNPN gene region by MS-PCR could be used for the PWS and AS molecular diagnostics. This test can rule out the clinical diagnosis of PWS $30 \%$ of patients.
\end{abstract}

Ke y w o r d s: Prader-Willi Syndrome, Angelman Syndrome, SNRPN gene, methyl-specific PCR.

\section{Introduction}

Prader-Willi syndrome (PWS) is characterized by hypotonia, failure to thrive with poor suck, hypogonadism, short stature with small hands and feet, hyperphagia leading to morbid obesity, beginning from early childhood; developmental delay/intellectual disability, and behavioral issues, including obsessive compul- sive disorder. The characteristic facial features are also evident. Angelman syndrome (AS) is characterized by developmental delay, intellectual disability, absent speech, seizures, ataxic gait, easily excitable happy demeanor, and characteristic faces.

PWS and AS typically result from the deletion of paternal for PWS or maternal for AS copies of the chromosome region 15q11-q13.

(C) 2018 S. Yu. Chernushyn et al.; Published by the Institute of Molecular Biology and Genetics, NAS of Ukraine on behalf of Biopolymers and Cell. This is an Open Access article distributed under the terms of the Creative Commons Attribution License (http://creativecommons.org/licenses/by/4.0/), which permits unrestricted reuse, distribution, and reproduction in any medium, provided the original work is properly cited 
Each one occurs with a frequency of approximately $1 / 15,000$ to $1 / 30,000$ live births [1], in the vast majority of cases they happen de novo, in families with no history of these syndromes.

Chromosome 15q11-q13 is a region that harbors several genes regulated by genomic imprinting, a phenomenon when genes are expressed preferentially from one parental allele. As a result, the genes subjected to regulation by genomic imprinting are functionally haploid, having only a single functional copy [2]. At least two genes $S N R P N$ and $N D N$ from the 15q11-q13 region have differentially methylated $\mathrm{CpG}$ islands in their promoter regions that are methylated on the maternal chromosome leading to the silencing of the maternal allele. The alteration of the paternal copy of the imprinted $S N R P N$ gene will cause PWS [3], and vice versa, the loss of maternal allele leads to AS. The other gene in this region, encoding the ubiquitin-protein ligase $\mathrm{E} 3 \mathrm{~A}-U B E 3 A$, is a parentally imprinted gene in which the paternal allele is selectively silenced in mature neurons. The promoter of $U B E 3 A$ gene is completely unmethylated and it is active on both parental copies in all tissues, silencing of the paternal allele expression is achieved by noncoding antisense transcript UBE3A-ATS [4], which is transcribed backwards to the $U B E 3 A$.

There are 4 known genetic mechanisms which can cause PWS and AS: de novo deletions involving the chromosome 15q11.2-q13 region, uniparental disomy (UPD) of 15q11.2q13, imprinting center (IC) defects and point mutations in the causative gene (Table 1). About $20 \%$ of cases of AS are caused by mutations in the UBE3A [5] but there are no instances of a point mutation in any gene caus- ing PWS, suggesting that PWS is a true contiguous gene syndrome, resulting from the loss of more than one gene.

Table 1. Genetic alterations lead to Prader-Willi and Angelman syndromes [6]

\begin{tabular}{|l|c|c|}
\hline \multicolumn{1}{|c|}{ Genetic mechanisms } & PWS & AS \\
\hline De novo deletions & $75-80 \%$ & $70-75 \%$ \\
UPD & $20-25 \%$ & $3 \%-7 \%$ \\
IC mutations (excluding & $1-2 \%$ & $1-2 \%$ \\
deletions) & $5-15 \%$ & $5-15 \%$ \\
IC deletions & - & $5-10 \%$ \\
UBE3A mutations &
\end{tabular}

The deletion of the 15q11.2-q13 locus occurs at a frequency of about $1 / 15,000$ newborns and is probably one of the most common pathogenic deletions observed in humans.

For molecular genetic diagnostics of PWS and AS, the most commonly used method is the analysis of the $S N R P N$ gene using FISH [7]. This method allows identifying only deletions in the studied region. Therefore, the use of methods capable of detecting UPDs and methylation defects significantly increase the informativeness of the molecular diagnosis of these syndromes.

The aim of the study was an estimation of 15q11.2-q13 rearrangements and epigenetic alterations frequency in the group of Ukrainian patients with PWS and AS clinical phenotype. The analysis of the $S N R P N$ gene alterations by methyl-spesific PCR was chosen because it allowed simultaneous testing of three types of alterations: deletions, UPDs and IC defects.

\section{Methods}

Group of 60 Ukrainian patients with PWS phenotype (18 females and 42 males) and 32 patients with AS phenotype (21 and 11 respec- 
tively) were referred from the regional medical genetics centers of Ukraine to the IMBG from 2011 to the present. The informed consent for clinical and genetic study was obtained from the patients statutory trustees in compliance with national ethics regulation.

DNA was extracted from the patients blood samples using proteinase $\mathrm{K}$ cell lysis and standard phenol-chloroform DNA purification. To identify methylation status of the $S N R P N$ gene all collected samples were analyzed by methylation-specific PCR (MS-PCR). Bisulfide (BS) conversion of genomic DNA was carried out using EZ DNA Methylation-GOLD ${ }^{\mathrm{TM}} \mathrm{Kit}$ (Zymo Research) according to the manufacturer's protocol. We used 1-2 $\mu \mathrm{g}$ of genomic DNA for BS- conversion, the converted DNA was diluted in 10-15 $\mu 1$ of the elution buffer. To find out the methylation status of the 15q11q13 locus we used PCR with two primers pairs: one specific to the $S N R P N$ gene BSconverted methylated DNA, second - to the $S N R P N$ gene BS-converted unmethylated DNA. PCR was carried out in a total volume of $20 \mu$ containing 1x FIREPol ${ }^{\circledR}$ Master Mix with $2.5 \mathrm{mM} \mathrm{MgCl}_{2}$ (Solis BioDyne), $0.75 \mu \mathrm{M}$ primers (both for the methylated and unmethylated BS-converted SNRPN gene fragments) and $10 \mu 1$ of BS-converted DNA solution. The PCR conditions were 1 cycle $-95^{\circ} \mathrm{C}$ for 5 min followed by 35 cycles of the 3 step protocol: $95^{\circ} \mathrm{C}-20 \mathrm{sec}, 62^{\circ} \mathrm{C}-30 \mathrm{sec}, 72^{\circ} \mathrm{C}-$ $30 \mathrm{sec}$. The MS-PCR results were visualized by $1.5 \%$ agarose gel electrophoresis and ethidium bromide staining.

\section{Results}

The MS-PCR technique used in this work allows the differential detection of both types of normal alleles of the SNPRP gene (methylated and unmethylated). The presence of two fragments (174 and $100 \mathrm{bp}$ ) corresponds to the presence of two normal homologues of the 15th chromosome: methylated, inherited from the mother (174 bp) and unmethylated - from the father (100 bp) (fig. 1). Thus, it is possible to reveal the presence of a deletion in methylated or unmethylated allele, a uniparent disomy (the presence of only 2 methylated or only 2 unmethylated alleles) and mutations in IC, leading to the absence of one or another type of allele. Based on the literature data presented in Table 1, PWS can occur only as a result of 3 types of alterations of the $15 \mathrm{q} 11.2$ chromosomal region: paternal deletions, maternal uniparent disomy or mutations in the IC. So, the analysis of the $S R N P N$ gene by MSPCR could detect about $100 \%$ of the alterations associated with PWS. Considering that in a third of cases AS is caused by the UBE3A mutations, the informativeness of the MS-PCR for this disease does not exceed $70 \%$. Additionally, one of the disadvantages is that this method, identifying 3 types of damage, does not allow their differentiation.

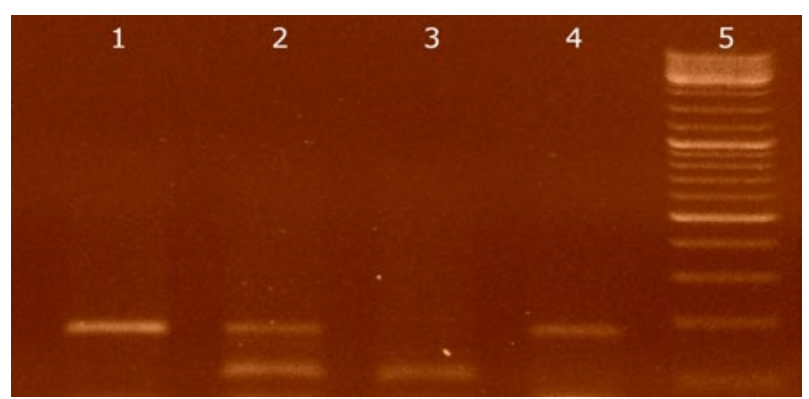

Fig. 1. Analysis of the $S N R P N$ gene in PWS and AS samples by MS-PCR, $1.5 \%$ agarose gel: 1,4 - patients with PWS; 2 - patient with normal methylation; 3 - patient with AS; 5 - ladder 100 bp. 
In the analyzed group of 60 patients with suspected PWS phenotype the absence of an unmethylated allele of the $S N R P N$ gene was observed in $42 \%$ of patients. These 25 patients have one of three possible genetic causes of PWS: paternal deletions, maternal UPDs or IC alterations of SNRPN.

In the AS group the frequency of $S N R P N$ methylated allele loss was detected in $28 \%$ (9 of 32) of patients. There are also 3 possible genetic causes - maternal deletions/paternal UPDs/IC, but the most likely one, based on literary data, is the deletion in the 15 q11.2 of maternal origin.

\section{Discussion}

The deletions of the chromosome 15q11.2-q13 region are typically diagnosed by fluorescence in situ hybridization (FISH) using the SNRPN probe [7]. With this method, it is possible to confirm the diagnosis in $60-70 \%$ of PWS and AS patients, but not those caused by UPDs or IC defects.

Based on the results obtained, it can be argued that the application of the MS-PCR technique to verify PWS is the most informative and low-cost in comparison with the FISH. However, in our study, close to $100 \%$ confirmation of PWS was not obtained. Lower than expected detection rate in the PWS group can be explained by the presence of patients with PWS-like syndromes. We can assume that proximal spinal muscular atrophy type I (SMA I, OMIM \# 253300) may be one of the probable diseases in children younger than 18 months when PWS was not confirmed. Both of these diseases SMA I and PWS are characterized by generalized hypotonia at the age of 12-18 months [8-9]. In case of PWS, these symptoms do not progress and are fade away when a patient reached the second year of life, in contrast to SMA I. This may be confirmed by the fact that in one patient with suspected PWS, we identified homozygous deletions in the SMN1 gene, which are major mutations in SMA I. Therefore, it is possible to recommend additional clinical and genetic studies to the patients under 18 months, who have idiopathic hypotonia, for differentiation of the diagnosis. Among clinical studies, the most informative, in our opinion, may be electromyography, which allows detecting muscular and neural alterations that lead to muscular or neuronal hypotonia and are not associated with PWS.

Moreover, in the PWS group we observed the significant prevalence of males - $70 \%$ (42 of 60 ), but the frequency of detected alterations in females was higher than in males - $56 \%$ (10 of 18 patients) and $36 \%$ (15 of 42) correspondently. This can indicate that less strict diagnostic criteria for males lead to incorrect over diagnostics of PWS in the current group.

The low detection rate in AS (28\%) could be due to both clinical misdiagnosis and limitations of the used method of molecular analysis. To improve the molecular diagnostics of AS, the further analysis of the AS associated genes, such as the $U B E 3 A$ and $M E C P 2$ genes should be done. We suggested that in addition to the mutations in the $U B E 3 A$ gene, the mutations in the $M E C P 2$ gene can lead to the AS phenotype. This assumption is based on the literature data about the similarity of the clinical phenotype in the patients with Rett syndrome and AS [10, 11].

\section{Conclusions}

Analysis of the $S R N P N$ gene region by MSPCR is cost-effective and high informative, 
therefore it could be implemented for the PWS and AS molecular diagnostics, rather than FISH. Our results revealed that the proposed molecular test can exclude the clinical diagnosis of PWS in approximately $60 \%$ of Ukrainian patients with suspected PWS. In $30 \%$ of the suspected AS patients, this analysis confirms the clinical diagnosis. Our nearterm plans include implementation of further molecular analysis of the AS associated genes, such as the $U B E 3 A$ and $M E C P 2$ genes, to improve the detection rate of molecular diagnostics of AS.

\section{Acknowledgements}

The authors would like to thank all clinical specialists from regional the medical genetic centers of Ukraine, for their participation in the survey of patients, support providing patients' samples and phenotype information. We wish to acknowledge the help in the methodological issues provided by Prof. Igor Lebedev and Prof. Ludmila Livshits, who supported the study planning, academic and technical staff of our department for their assistance. We are also grateful to the patients and members of their families for their kind consent to participate in the study.

\section{REFERENCES}

1. Kalsner L, Chamberlain SJ. Prader-Willi, Angelman, and 15q11-q13 Duplication Syndromes. Pediatr Clin North Am. 2015;62(3):587-606.

2. Choufani $S$, Weksberg $R$. Genomic imprinting. Funct Nucl. 2016; 4(1): 449-65.

3. Sharp AJ, Migliavacca E, Dupre Y, Stathaki E, Sailani MR, Baumer A, Schinzel A, Mackay DJ, Robinson DO, Cobellis G, Cobellis L, Brunner HG, Steiner B, Antonarakis SE. Methylation profiling in individuals with uniparental disomy identifies novel differentially methylated regions on chromosome 15. Genome Res. 2010;20(9):1271-8.

4. LaSalle JM, Reiter LT, Chamberlain SJ. Epigenetic regulation of UBE3A and roles in human neurodevelopmental disorders. Epigenomics. 2015;7(7):1213-28.

5. Kishino T, Lalande $M$, Wagstaff $J$. UBE3A/E6-AP mutations cause Angelman syndrome. Nat Genet. 1997;15(1):70-3.

6. Ramsden SC, Clayton-Smith J, Birch R, Buiting K. Practice guidelines for the molecular analysis of Prader-Willi and Angelman syndromes. BMC Med Genet. 2010;11:70.

7. Smith A, Robson L, St Heaps L. Use of two FISH probes provides a cost-effective, simple protocol to exclude an imprinting centre defect in routine laboratory testing for suspected Prader-Willi and Angelman syndrome. Ann Genet. 2002;45(4):189-91.

8. Elsheikh BH, Kissel JT. Spinal Muscular Atrophies. In: Eds. Katirji B, Kaminski H, Ruff R. Neuromuscular Disorders in Clinical Practice. Springer, New York, NY;2014:425-39.

9. Риiи M, Сиси N. Prader - Willi Syndrome, from Molecular Testing and Clinical Study to Diagnostic Protocols. Rijeka: “InTech", 2011; 472 p.

10. Watson P, Black G, Ramsden S, Barrow M, Super M, Kerr B, Clayton-Smith J. Angelman syndrome phenotype associated with mutations in MECP2, a gene encoding a methyl $\mathrm{CpG}$ binding protein. $J$ Med Genet. 2001;38(4):224-8.

11. Hitchins MP, Rickard S, Dhalla F, Fairbrother UL, de Vries BB, Winter R, Pembrey ME, Malcolm S. Investigation of UBE3A and MECP2 in Angelman syndrome (AS) and patients with features of AS. Am J Med Genet A. 2004;125A(2):167-72.

\section{Аналіз генетичних та епігенетичних мутацій гена $S N R P N$ у паціснтів з синдромами Прадера- Віллі та Ангельмана}

С. Ю. Чернушин, Н. В. Грищенко

Синдроми Прадера-Віллі (СПВ) та Ангельмана (СА) це різні за клінічними ознаками генетичні захворювання, які супроводжуються фізичними та когнітивними розладами. Генетичною причиною СПВ та СА $\epsilon$ пошкодження в хромосомній ділянці 15q11.2-q13, експресія генів якої підлягає геномному імпринтингу. 
Мета. Оцінка частоти геномних перебудов та епігенетичних порушень в 15q11.2-q13 у групі пацієнтів 3 України, які мали фенотипові прояви СПВ та СА. Методи. Для одночасної детекції як генетичних, так i епігенетичних порушень, які призводять до СПВ та $\mathrm{CA}$, аналізувався статус метилування гена $S N R P N \quad 3$ використанням метил-специфічної ПЛР (МС-ПЛР). Результати. Порушення, яке призводить до СПВ відсутність неметильованого гена $S N R P N$ - було виявлено у 25 (42\%) хворих з фенотипом СПВ. В групі з СА частота мутацій $S N R P N$ (відсутність гіпометильваного гена) виявлена у $28 \%$ хворих. В групі 3 СПВ відмічено достовірне переважання пацієнтів чоловічої статі. Проте частка жінок з підтвердженим діагнозом в цій групі була вищою - 56 \% проти $36 \%$. Менший за очікуваний відсоток підтвердження СПВ та СА може бути наслідком як помилок клінічної діагностики, так і методичних обмежень. Висновки. Аналіз ділянки гена $S R N P N$ з використанням МС-ПЛР може бути запропонований для молекулярної діагностики СПВ та СА. Прогнозується, що використання цього методу тестування дозволяє виключити діагноз СПВ у приблизно 60 \% хворих з клінічними ознаками цього синдрому, у 30 \% пацієнтів з ознаками СА підтвердити захворювання.

К л ю ч о в і с л о в а: синдром Прадера-Віллі, синдром Ангельмана, ген $S R N P N$, метил-специфічна ПЛР.

\section{Анализ генетических и эпигенетических мутаций гена $S N R P N$ у пациентов} с синдромами Прадера-Вилли и Ангельмана

С. Ю. Чернушин, Н. В. Грищенко

Синдромы Прадера-Вилли (СПВ) и Ангельмана (CA) - это разные по клиническим признакам генетические заболевания, которые сопровождаются фи- зическими и когнитивными расстройствами. Генетической причиной СПВ и СА является повреждение в хромосомной области 15q11.2-q13, экспрессия генов которой подлежит геномному импринтинуг. Цель. Оценка частоты геномных перестроек и эпигенетических нарушений в 15q11.2-q13 в группе пациентов с Украины с фенотипическими проявлениями СПВ и СА. Методы. Для одновременной детекций как генетических, так и эпигенетических нарушений, которые приводят к СПВ и СА, анализировался статус метилирования гена $S N R P N$ с использованием метил-специфической ПЦР (МС-ПЦР). Результаты. Нарушение, которое приводит к СПВ - отсутствие неметильованого гена $S N R P N$ - было обнаружено у 25 (42\%) больных с фенотипом СПВ. В группе с СА частота мутаций $S N R P N$ (отсутствие гипометильваного гена) выявлено у 28 \% больных. В группе с СПВ отмечено достоверное преобладание пациентов мужского пола. Однако доля женщин с подтвержденным диагнозом в этой группе была выше - 56 \% против $36 \%$. Меньший ожидаемого процент подтверждения СПВ и СА может быть следствием как ошибок клинической диагностики, так и методических ограничений. Выводы. Анализ участка гена $S R N P N$ с использованием МС-ПЦР может біль предложен для молекулярной диагностики СПВ и СА. Прогнозируется, что использование этого метода тестирования позволяет исключить диагноз СПВ у примерно 60 \% больных с клиническими признаками этого синдрома, у 30 \% пациентов с признаками СА - подтвердить заболевания.

К люче в ы е с лов а: синдром Прадера-Вилли, синдром Ангельмана, ген $S R N P N$, метил-специфическая ПЦР.

Received 01.08.2018 